Georgia State University

ScholarWorks @ Georgia State University

$10-2-2008$

\title{
Elimination of Gender-Related Employment Disparities through Statistical Process Control
}

\author{
Mary E. Graham \\ Federal Reserve Bank of Atlanta, graham@clarkson.edu \\ Julie E. Hotchkiss \\ Georgia State University, julie.I.hotchkiss@atl.frb.org
}

Follow this and additional works at: https://scholarworks.gsu.edu/uwrg_workingpapers

\section{Recommended Citation}

Graham, Mary E. and Hotchkiss, Julie E., "Elimination of Gender-Related Employment Disparities through Statistical Process Control" (2008). UWRG Working Papers. 29.

https://scholarworks.gsu.edu/uwrg_workingpapers/29

This Article is brought to you for free and open access by the Usery Workplace Research Group at ScholarWorks @ Georgia State University. It has been accepted for inclusion in UWRG Working Papers by an authorized administrator of ScholarWorks @ Georgia State University. For more information, please contact scholarworks@gsu.edu. 
Working Paper 2008-10-2

October 2008

\section{Elimination of Gender-Related Employment Disparities through Statistical Process Control}

Mary E. Graham

Federal Reserve Bank of Atlanta

Julie L. Hotchkiss

Georgia State University 
Elimination of Gender-Related Employment Disparities through Statistical Process Control

Mary E. Graham and Julie L. Hotchkiss

Working Paper 2008-24

October 2008

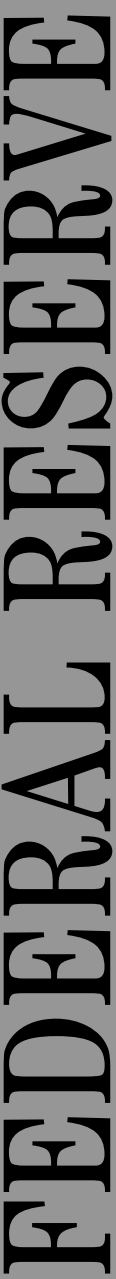




\title{
Elimination of Gender-Related Employment Disparities through Statistical Process Control
}

\author{
Mary E. Graham and Julie L. Hotchkiss
}

Working Paper 2008-24

October 2008

\begin{abstract}
This paper proposes a novel approach that has the potential to hasten the eradication of gender disparities in employment. This approach relies upon the concept of statistical process control (SPC) to more systematically remedy disparate employment outcomes for women. SPC also serves as a new vehicle for conceptualizing the influence of industry on equal employment opportunity (EEO) outcomes. Using data from U.S. Current Population Surveys, we compare industries on EE0 performance as assessed by a recently developed Systemic Gender Disparity Scorecard. The theory and practice of SPC suggest that further improvement, and by far the greater opportunity for gender-related EE0 progress, necessitates fundamental changes in each industry's practices and norms that serve as barriers to gender parity. We recommend more resources to support collaboration between employers and EEO enforcement agencies.
\end{abstract}

JEL classification: J78, M12

Key words: equal employment opportunity, statistical process control, discrimination, wage differentials

An earlier version of this paper was presented at the 2006 Academy of Management Meetings in Atlanta. Authors' names are in alphabetical order; each contributed equally to the paper. The views expressed here are the authors' and not necessarily those of the Federal Reserve Bank of Atlanta or the Federal Reserve System. Any remaining errors are the authors' responsibility.

Please address questions regarding content to Mary E. Graham, Clarkson University, P.0. Box 5790, Potsdam, NY 13699, 315-2686431, graham@clarkson.edu, or Julie Hotchkiss, Research Department, Federal Reserve Bank of Atlanta, 1000 Peachtree Street, N.E., Atlanta, GA 30309-4470, 404-498-8198, julie.l.hotchkiss@atl.frb.org.

Federal Reserve Bank of Atlanta working papers, including revised versions, are available on the Atlanta Fed's Web site at www.frbatlanta.org. Click "Publications" and then "Working Papers." Use the WebScriber Service (at www.frbatlanta.org) to receive e-mail notifications about new papers. 


\section{Elimination of Gender-Related Employment Disparities through Statistical Process Control}

\section{Introduction and Background}

The median gender earnings ratio in the United States stands at .80, with full-time working women in 2007 earning 80 cents for every dollar earned by men (U.S. Department of Labor, 2007). Employment discrimination explains at least part of the gender earnings gap; other explanations include women working in fields, employers, and industries that pay less than those in which men work; women's lower levels of human capital; and fewer hours worked by women (Blau, Ferber, and Winkler, 2006). Unfortunately, the multiple sources of the gender earnings gap are virtually impossible to disentangle fully, a primary problem being disagreement over the characterization of worker behavior that is neither clearly voluntary nor clearly the result of employment discrimination (Weichselbaumer and Winter-Ebmer, 2006).

We do not resolve this issue. Instead we offer a unique, industry-based approach to tackling persistent gender disparities in earnings and employment in the U.S. economy. We propose that through the principles and tools of statistical process control (SPC), enforcement agencies can more accurately identify discriminatory employers for investigation, enforcement, and/or assistance (Deming, 1986). Although SPC theories typically focus on production processes, it also makes sense to apply them to employer human resource management processes and resultant EEO outcomes (MacCarthy and Wasusri, 2002). Application of SPC to the employment context underscores the point that system factors are substantially more determinant of EEO outcomes than currently recognized, raising the possibility of a fundamental mismatch between public policy and the nature of employment discrimination. 
With its focus on outcomes, SPC is also an ideal tool with which to tackle complex types of discrimination that may be less visible than discrimination of the past. Today's discrimination may be more likely to accumulate over time, occur across multiple human resource management practices, or stem from subconsciously-held attitudes (Bendick, 2007; Graham, Hotchkiss and Gerhart, 2000; Reskin, 2000). Seemingly in tune with complex forms of employment discrimination, the primary federal enforcers of employment discrimination laws in the U.S. -the Equal Employment Opportunity Commission (EEOC) and the Office of Federal Contract Compliance Programs (OFCCP) - recently intensified their focus on systemic employer discrimination, or "pattern or practice, policy and/or class cases where the alleged discrimination has a broad impact on an industry, profession, company, or geographic location" (Silverman, 2006). For example, the EEOC doubled the number of systemic charges from fiscal year 2006 (11 charges) to fiscal year 2007 (24 charges), and substantially increased the number of class action charges (U.S. EEOC, 2007a). Similarly, the OFCCP in its compliance reviews of federal contractors now assesses whether gender- or race under-representation may stem from systemic discrimination (Silberman, 2008). But these systemic approaches, as practiced, may actually worsen EEO performance over time because they violate some basic tenets of SPC (Shewhart, 1939). These tenets include: (a) recognition that the majority of variation in outcomes is due to “common" causes (i.e., the influence of similar factors across all employers in an industry) as opposed to "special" causes (i.e., the actions of individual employers); and (b) management intervention only for purposes of remedying problems that are clearly attributable to special causes, based upon formal outlier identification procedures.

We incorporate industry into our statistical process control (SPC) application since the employment processes of firms are shaped to a large extent by industry norms, practices, and 
industries' economic and business environments (Baron and Bielby, 1980; Gersen, 2007; Krueger and Summers, 1988). Firm-level, gender-related employment disparities are enduringly intertwined with the industries in which they occur. In addition, the form of gender disparities will vary by industry. In SPC terms, then, industry can be considered a "common" cause of gender disparities because all firms within an industry are affected. ${ }^{1}$ This highlights the fact that the meager public resources currently devoted to collaborative, industry-based EEO interventions are inversely related to their potential impact.

To summarize, we propose an application of theories of SPC, and an outcomes-based Gender EEO Scorecard at the industry level, to address three shortcomings in current U.S. government anti-discrimination efforts: (1) an atheoretical approach to prioritizing and designing agency enforcement efforts; (2) an inadequate emphasis on the industry setting(s) in which employing firms operate, and (3) the lack of systemic tools for joint consideration of all parts of the employment process: pay, hiring, job placement, and promotion, for multiple protected classes (e.g., gender and race).

An underlying assumption of this paper is that raising the gender earnings ratio is a worthy goal, regardless of the degree to which employment discrimination is involved. This is because women's lower earnings have negative implications for their work participation decisions, earnings, and long-term economic security (Rose and Hartmann, 2004). Furthermore, there are potential competitive and equity costs associated with gender-related disparities in employment (McAdams, 1995).

We begin the paper with an introduction and application of statistical process control to the EEO enforcement context, followed by a discussion of the importance of industry setting to understanding gender-related employment disparities. After introducing the Systemic Gender 
EEO Scorecard, we suggest better ways of identifying employers for systemic discrimination enforcement and ideas for accelerated improvements to women's employment outcomes. As part of the latter we provide an empirical illustration with Current Population Survey data. Finally, we generate policy recommendations for EEO agencies.

\section{A New Theoretical Lens: Statistical Process Control and EEO Performance}

\section{A. Introduction to SPC}

Statistical process control, a method used primarily for improving production processes in manufacturing settings, is a key tool of total quality management programs and successor Six Sigma initiatives, all of which aim to prevent product defects rather than remedy them postproduction (Rath and Strong, 2003). SPC rests on the premise that all processes exhibit both random and non-random variation, and that the type of variation provides clues as to the most effective process improvement interventions (Shewhart, 1939). Managers and engineers track production data through "control charts" to detect patterns and outliers that indicate non-random, or special, causes of variation that need further investigation. SPC and control charts are essentially analysis of variance techniques in formats that are more accessible to managers and employees (Kolesar, 1993a).

In the total quality management setting, work teams typically isolate and try to eliminate special causes of variation in order to stabilize production processes and render them more predictable. The creation of a stable process is a necessary condition for further process improvements, because only stable processes will exhibit the normal distribution of observations necessary for probabilistic inferences about processes (Shewhart, 1939; Tukey, 1977 as cited in Deming, 1986). Importantly, erroneously attributing variation to special causes and designing 
corresponding remedies will destabilize and actually increase process variation (Deming, 1986; Shewhart, 1939).

In the SPC literature there is a widespread assumption that the majority of process variation is attributable to common factors, or inherent process features (Shewhart, 1939; Latzko and Saunders, 1995). For example, Deming estimates that common causes account for $94 \%$ of total variation in production processes, and that special causes account for only the remaining 6\% (Deming, 1986: 315). However, an empirical examination of 66 industry cases revealed that for unstable processes, common cause variation comprised a minimum of $30 \%$ of total variation, with an average of $50 \%$ (Grabov, 1998). It also appears that the proportions of special and common causes of variation depend in part upon the assumptions regarding the relative impact of workers and systems on work outputs (Anderson, Rungtusanatham, and Schroeder, 1994; Kolesar, 1993a). Nevertheless, almost all scholars and practitioners acknowledge substantial, consequential common cause influence on production variation. ${ }^{2}$

\section{B. SPC and Current EEO Enforcement Efforts}

The Equal Employment Opportunity Commission (EEOC) of the U.S. Department of Labor enforces employment discrimination statutes (e.g., Title VII of the Civil Rights Act of 1964) through the following efforts: a) collecting annual EEO-1 staffing data from employers with 100 or more employees or federal contractors with 50 or more employees; b) receiving, investigating, conciliating, and litigating employment discrimination complaints; c) initiating systemic discrimination charges against employers with potentially egregious or widespread discriminatory practices; and d) educating and offering assistance to employees and employers on EEO requirements and procedures. The Office of Federal Contract Compliance Programs (OFCCP) of the U.S. Department of Labor oversees the EEO efforts of federal contractors by 
monitoring required affirmative action plans, auditing employers on their compliance efforts, and to a lesser extent, conducting employer outreach and education, and receiving employee complaints. ${ }^{3}$ The EEOC tends to perform a larger number of investigations with smaller employer sanctions, while the OFCCP does fewer investigations that produce larger sanctions (Edwards, 1991/1992). The OFCCP has more legislative authority and flexibility than the EEOC in obtaining employer data; however, the political influence of employer groups, limited resources, and legislation such as the Paperwork Reduction Acts of 1980 and 1995 (U.S. Department of Commerce, 2008), place practical limits on both agencies.

The current enforcement strategies of the EEOC and OFCCP are aligned only partially with SPC tenets. Neither the EEOC's newly revamped systemic discrimination charge system nor the OFCCP's recent systemic emphasis in its audits appear to rely on any theoretical justification for identifying poor EEO performance relative to other firms in the industry. The EEOC's current system of developing systemic discrimination charges based upon the judgments of district offices and other compilations of anecdotal evidence (Silverman, 2006) and the OFCCP's formula for selecting employers for compliance audits (2008c) potentially would be characterized as harmful tampering according to SPC theories (Deming, 1986). The systemic enforcement processes of both agencies are described in more detail in the following section.

If common causes of variation in employment processes predominate as suggested by SPC theories, then in order to fully and most dramatically address gender-related employment disparities in the U.S. economy, entire systems of employment must be improved. At present, however, the EEOC and the OFCCP place little priority on system-wide outreach and education interventions. For example, in Fiscal Year 2007, the EEOC devoted approximately 5.2\% of its expenditures to outreach and the training on EEO compliance, with almost its entire budget 
devoted to enforcement and litigation aimed at individual employers. ${ }^{4}$ To summarize, we are making the case for parsing the sources of gender-related employment disparities into common causes and special causes in order to highlight why an expansion of EEOC and OFCCP activities is necessary.

\section{Industry Context as a Critical Common Cause of EEO Performance}

\section{A. Linking Firm Behavior at the Industry Level}

The industries in which firms operate influence firm-level economic performance, employment processes, and the levels of gender-related employment disparities in the U.S. economy (Baron and Bielby, 1980). To a substantial degree, firms in the same industry will experience similar outcomes across business cycles and over time, due to the influence of industry characteristics of product demand, domestic and international competition, growth rates, profitability, technological advancements, and other factors (McGahan and Porter, 2002; Short, Ketchen, Palmer and Hult, 2007). Arguably, some industry influences are more stable (e.g., industry structure) than others (e.g., business cycles) (Hawawini, Subramanian, and Verdin, 2003).

Industry is a key component of the social structures in which firms operate (Krueger and Summers, 1988; White, 1981). Firms are subject to normative, resource-dependence, and economic pressures to conform to accepted industry practices (Alessandri and Khan, 2006; DiMaggio and Powell, 1983), including employment processes that reflect discriminatory norms or "tastes" for discrimination (Black and Brainerd, 2002; Gersen, 2007; Johnson and Solon, 1986). The supply-side determinants of employment outcomes, which are not the focus of our paper, are best described from a human capital perspective and manifest themselves in differences across educational levels and occupational attainment (Becker, 1993). ${ }^{5}$ 
The intensity of the institutional pressures to which firms are subject can vary over time and as a function of market forces (Dacin, 1997). Not surprisingly, firm responses to these pressures will vary as well, based upon firm characteristics such as size, age, and the degree of embeddedness in the industry (Granovetter, 1985; Miller and Chen, 1996). This is important because economic performance is related to the exercise of discriminatory power (for example, see Hotchkiss and Pitts, forthcoming). In addition, less-regulated industries will have more leeway to discriminate than more-regulated industries (Johnson, 1978). Despite these complexities, the fact remains that industry-based relationships will be among firms' closest and most influential connections with other firms.

Generally, neoclassical economic theory posits that competition and profit penalties for discriminators will eliminate employment discrimination. There is empirical support for the contention that product market competition reduces employment discrimination over time (Ashenfelter and Hannan, 1986; Peoples and Heywood, 2006). On the other hand, firms' responses to these pressures may be inhibited by industry norms and imperfect markets (Akerlof, 1985; Coleman, 2004); as well as human tendencies to favor similar others as a means to enhance individual well-being (Ashforth and Mael, 1989; McAdams, 1995; Wooten and James, 2004).

\section{B. Consideration of Industry in Current EEO Efforts}

1. EEOC. The 2007-2012 strategic plan of the EEOC (U.S. EEOC, 2006) calls for proactive prevention of employment discrimination and the use of strategic enforcement and litigation; however, the lack of attention to industry context diminishes the power of the document. In the strategic plan, prevention strategies focused on educating workers and managers do not refer to the industries in which individuals reside nor do they recognize that various industries may house 
or perpetuate different types of discrimination. This is a critical oversight. In addition, the plan devolves strategic planning regarding systemic discrimination to each of the 15 EEOC district offices, enabling inconsistent emphases on industry context.

To a certain extent, the EEOC has considered industry in carrying out its responsibilities for many years (Ronald Edwards, Ph.D., Director of Program Research and Surveys Division, Office of Research, Information and Planning, EEOC, personal interview, June 21, 2007). Statistical analyses to support or initiate complaint investigations are more comparable for job groups within the same industries. In addition, EEOC field offices may share information about cases occurring in the same industries, and EEOC researchers have examined industry-based options for identifying systemic discriminators (Cartwright and Edwards, 2003). In sum, there appears to be some, but not overwhelming, consideration of industry by the EEOC at present. 2. OFCCP. The OFCCP has an advantage over the EEOC in terms of greater access to employer data through its routine compliance audits of federal contractor affirmative action plans. ${ }^{6}$ From 2001-2007, an average of approximately 4,500 compliance audits were conducted per year, or about $2.4 \%$ of the approximately 93,000 non-construction and 100,000 construction firms that are federal contractors (U.S. Department of Labor, 2008a, 2008b). The audits can encompass all employment activities. In the 1970's, the OFCCP selected contractors for compliance reviews with what appeared to be unsystematic, ad hoc processes, despite having formal targeting systems available (Heckman and Wolpin, 1976; Leonard, 1985). The informality of the OFCCP at this time resulted in the counterintuitive result that the firms with the lowest proportions of women and minorities were the least likely to be reviewed (Leonard, 1985). From the mid-1980s until 2000, the OFCCP selected contractors for review using the Equal Employment Data System (EEDS), which compared staffing rates by gender and race/ethnicity based upon EEO-1 data to 
industry and regional averages, and it relied to a lesser extent upon the discretion of OFCCP district directors to flag firms for compliance audits (Federal Register, 2006a; U.S. General Accounting Office (GAO), 1995).

The Clinton Administration instituted an extensive firm-level Equal Opportunity Survey (EOS) on pay and other employment outcomes, one aim of which was to target federal contractors with poor EEO records (Hodgson and Cooper, 2000). However, in 2006 the EOS was replaced by the current Federal Contractor Selection System (FCSS), which relies in part on an externally-developed statistical formula for selecting federal contractors for compliance reviews (U.S. Department of Labor, 2008c). The OFCCP takes pains to emphasize the "neutrality" of its current audit selection procedures, defining neutrality as subjecting all contractors to the same audit selection criteria (Patsy Blackshear, Ph.D., OFCCP Director of Program Operations, personal interview, February 12, 2008). However, the OFCCP website indicates that the factors of establishment size and other "multiple factors" are utilized to identify "the likelihood of finding systemic discrimination" by a particular contractor (U.S. DOL, 2008c). It is unclear whether the OFCCP oversamples firms in industries with high complaint rates or with histories of underrepresentation of women and minorities, but contractor performance is normed within industry (U.S. DOL, 2008c) and the agency acknowledges concentrating its resources on the “worst offenders" (U.S. DOL, 2008d).

\section{Illustration of SPC in EEO Enforcement}

\section{A. Overview}

We provide a roadmap for and illustration of the use of SPC in EEO enforcement, using Current Population Survey data and the Systemic Gender Disparity Scorecard, which we discuss in the next section. This proposed application of SPC by federal enforcement agencies involves 
the identification and remediation of special causes of within-industry EEO variation, followed by industry-wide problem-solving initiatives tailored to the industry or industries in which employers operate. The latter step is the focus of this paper, although the first step is discussed also. With this illustration we aim to render visible our contention that the SPC approach is superior to the current enforcement strategies in terms of theoretical soundness and the potential to eliminate gender-related employment disparities more quickly.

\section{B. The Systemic Gender Disparity Scorecard as a Means to Assess EEO Progress}

The Systemic Gender Disparity Scorecard is a proposed comprehensive tool for assessing gender-related EEO performance at the employer or industry level (cite blinded). Because the Scorecard assesses multiple types of gender-related employment disparities simultaneously, it recognizes the possibility that firms that do not discriminate in one activity (e.g., hiring), may discriminate in others (e.g., promotions); and that the forms of discrimination may shift in the presence of enforcement attention or other factors.

The five components of the G-EEO Scorecard are as follows (additional detail on the construction of each component, and how the components are combined into a single index, is presented in Appendix A):

1) The "Equal Pay Component" measures the extent to which the employer pays women and men in the same jobs and the same human capital characteristics the same pay.

2) The "Occupational Segregation Component" measures the extent to which an employer's workforce is integrated, by gender, across jobs and occupations.

3) The "Glass Ceiling Component" measures the extent to which women are represented in the upper levels of the organization. 
4) The "Hiring Component" measures the extent to which women and men are proportionally represented in occupations and firms relative to their levels of availability in the relevant labor market.

5) The "Related Discrimination Component" considers the scores on the separate components from the perspective of race/ethnicity. ${ }^{7}$

The Scorecard provides a more comprehensive picture of EEO performance than current methods, because it evaluates all aspects of the employment process. For example, both the OFCCP and EEOC sometimes analyze employers' annual EEO-1 reports for potential signs of systemic discrimination, but EEO-1 reports contain only staffing data, to the neglect of information on other important employment decisions (e.g., pay levels) covered by Title VII of the Civil Rights Act of 1964. Underscoring this point, human resource management scholars recognize that staffing is but one part of an inter-related human resource system (Becker, Huselid, and Ulrich 2001; Petersen and Saporta, 2004). In addition, the Scorecard also has advantages over gender claim rate data because complaint filing statistics may be driven by factors other than the actual degree of discrimination (Goldman, 2003; Stangor, Swim, Van Allen, and Sechrist, 2002).

\section{Step 1: Identification of Special Causes}

The first step in the SPC process is to chart EEO outcomes for firms in each industry, for purposes of identifying special causes of variation for further investigation. In order to ensure that these special causes will be identifiable, Shewhart (1939) and subsequent quality experts recommend parsing the data into meaningful subgroups. We examine broad industry subgroups. Two types of charts are useful in the context of our paper: 1) a range chart, which highlights unusually wide variation in an employer's EEO outcomes over time; and 2) an X-bar chart, 
which draws attention to employers with unusually high or low EEO performance relative to other firms in the industry. Standard SPC procedure recommends that poorly performing firms be investigated further for the possibility of systemic discrimination charges by the EEOC or sanctions by the OFCCP. It is expected that these "hard core discriminators" will constitute between 6.5\% and 12\% of employers (Bendick and Egan, 2000; Federal Register, 2006b).

Consistent with the need to minimize "false positives" or erroneous conclusions that an employer is a systemic discriminator when it is not (i.e., Type I error), the identification of employers should focus only on extreme outliers or unusual patterns of variation. ${ }^{8}$ According to conventional industry practice, this means attending to only those employers performing at least 3 standard deviations worse than the industry average (Kolesar, 1993a; Shewhart, 1939). Alternatively, the threshold could be set at 6 standard deviations from the mean, consistent with Six Sigma quality programs (Rath and Strong, 2003). ${ }^{9}$ Figure $1 \mathrm{~A}$ presents a range chart and Figure 1B presents an X-bar control chart for hypothetical data on firms in the service industry. ${ }^{10}$

\section{[Insert Figure IA and Figure IB about here]}

Figure IA graphs each employer's range of EEO Scorecard values (i.e., highest EEO scores minus lowest EEO scores) over a 5-year period, for 30 hypothetical employers. ${ }^{11}$ The Scorecard ranges from 0 (good performance) to 1 (poor performance) by design, and the employer data in Figure IA range from .059 to .20. Employer 5's range of .20 exceeds the three standard-deviation threshold, indicating that Employer 5 has a range of EEO scores that greatly exceeds other firms' in the industry. This finding warrants further investigation. From an enforcement standpoint, the EEOC or OFCCP would be interested in performance declines that appear to reflect discrimination. 
The X-bar chart, which reports each employer's EEO score for one year, is more relevant than the range chart in an EEO context. Figure IB indicates that Employer 16's EEO performance is more than 3 standard deviations worse than other employers in the industry. Again, the federal enforcement agencies should investigate this situation further to assess whether there is a plausible explanation for this result or whether it signals systemic discrimination. No other employer would be flagged for systemic enforcement attention because they are exhibiting normal random variation for the industry in which they are situated. The fact that all of the other employers' ranges fall within the three standard-deviation control limits is positive in that it indicates some degree of process stability (Deming, 1986).

\section{Step 2: Identification of Common Causes of EEO Variation Within Industry Subgroups}

We begin with the SPC assumption that employment outcome variation within industries is due substantially and perhaps primarily to system factors or common causes (Deming, 1986). As discussed throughout this paper, we focus on industry as a key common cause of employer EEO performance, and we recognize that different industries may have different common causes of gender-related EEO performance. To help prioritize which industries should receive the most enforcement attention, and to provide clues as to the nature of industry influences, we recommend cross-sectional and longitudinal analysis of the Systemic Gender EEO Scorecard data, by industry.

To illustrate this approach, we compiled data from the combined outgoing rotation groups from the March, April, May, and June Current Population Surveys (CPS) for 1989-2000, reporting the cross-sectional results for the year 2000. CPS samples from each month were matched to the March file in order to obtain important determinants of labor market participation 
(used in the estimation of wage outcomes). These months are combined in order to obtain as large a sample of workers in each industry as possible.

In the CPS, each industry in the data is comprised of multiple employers producing similar goods or services. Six broad industry groups are analyzed: manufacturing; mining and construction; transportation, communication, and utilities; retail and wholesale trade; service; and finance, insurance, and real estate. ${ }^{12}$ In the CPS data, we examine 33,662 observations (std. dev. 3,703) in the year 2000, and the average sample size for the years $1989-2000$ is $35,937 .{ }^{13}$ Table I contains some means across industries for the year 2000. The service, retail and wholesale trade, and manufacturing are the industries employing the greatest percentages of workers. The representation of women is lowest in the mining and construction industry and highest in the finance, insurance, and real estate industry and in the service industry.

\section{[Insert Table I about here]}

Table II presents the EEO Scorecard components and results for each industry in the year 2000. The component values are reported along with their standardized values (in bold). The standardized values demonstrate if performance on any one component is one standard deviation different than the market average. ${ }^{14}$ A negative value indicates that the industry is performing worse than the market average, and a positive value means the industry is performing better than the market average, and the overall Scorecard is standardized in the same way. The five components combine to produce an overall Scorecard for each industry reported in the last row of Table II.

\section{[Insert Table II about here]}

Both the manufacturing, and retail and wholesale trade industries performed within one standard deviation of the market average on all components, resulting in Scorecard values that 
also fall within market norms. The service industry performed above market norms in all but one component, resulting in a Scorecard for that industry that is farthest above the market norm overall. The finance, insurance, and real estate industry is overall slightly above the market norm, with poor performance in Equal Pay being offset by good performance on the Glass Ceiling and Related Discrimination components. Both the mining and construction industry, and the transportation, communication, and utilities industry have scores below the market norm. The mining and construction industry's poor Scorecard was driven by its significantly below average performance on three out of the five components. The poor performance by transportation, communication, and utilities on the Hiring Component was enough to push that industry outside the market norm overall.

The Systemic Gender EEO Scorecard can be mapped over time as well to illustrate trends in industries' EEO performances and to establish the robustness of the cross-sectional results. We plotted each industry's annual standardized Scorecard for the years 1989-2000. These results indicate that mining and construction industry has fallen consistently below the market norm. And while consistently above the market norm, the service industry has shown a slight, steady decline over the time period $(\mathrm{p}<.05)$. Finance, insurance, and real estate is an example of an industry that has improved its performance over the period $(\mathrm{p}<.01)$, falling above the market norm in the most recent two years. All other trends are not significant. We interpret this trend analysis with some caution as it does not fully consider changes in industry composition and structure over time (Tomaskovic-Devey, Zimmer, Stainback, Robinson, Taylor, and McTague, 2006).

\section{[Insert Figure II about here]}


We also obtained EEOC complaint data by industry through a Freedom of Information Act Request, in order to compare complaint rates with our results. We find that complaint rates and Scorecard values are correlated significantly, providing some evidence of the validity of the Scorecard metric. Specifically, the Scorecard results over time are positively correlated with EEOC complaints by industry $(r=.85 ; \mathrm{p}<.01)$, for the years $1992-2000$, which is similar to the results found by Gersen (2007). The Scorecard results also parallel the ranking of industries by complaint rate data.

\section{Discussion}

\section{A. EEO Enforcement, Statistical Process Control and Industry}

Our paper offers a new industry-based approach to eradicating gender disparities in employment. We apply the lens of statistical process control theory from the quality management literature (Deming, 1986; Shewhart, 1939) to the federal enforcement of EEO laws, for the purpose of accelerating EEO progress in a manner that is theoretically sound, resource efficient, and fair to employers and employees. We also hope to redirect the stalled discussion regarding the precise amount of employment discrimination in the U.S. economy, toward a dialogue about potential collaborative efforts between enforcement agencies and industry trade groups. Our paper is motivated in part by past and current research that raises serious questions regarding the rationality and efficacy of EEOC and OFCCP's enforcement efforts (Heckman and Wolpin, 1976; Hirsh, 2008; Leonard, 1985), particularly given today's more complex forms of gender discrimination (Graham et al., 2000; Krieger and Fiske, 2006).

Incorporating SPC into EEO enforcement methods represents a major improvement over less formal methods of systemic discrimination charge development currently utilized by the EEOC and OFCCP. SPC has the added advantage of being diffused widely, and it is accepted in 
the business world as an effective continuous improvement approach (Corbett, Montes-Sancho, and Kirsch, 2005). SPC relies upon basic theories of distribution, variation, and probability to balance the interests of employers and employees in ensuring that systemic discriminators are likely to be detected and that non-discriminators are not selected for enforcement action. Control charts for each industry help identify when employer-level intervention is necessary and when it will result in (undesirable) wider variation in employer EEO performance. The empirical analyses in this paper were not designed to predict which industries might contain the greatest number of poorly performing outliers. However, reductions in the number of outliers should be seen in each industry over time as the intervention methods described in this paper are applied. An even greater contribution of SPC to the EEO enforcement process, however, is its potential to accelerate reductions in the gender earnings gap and in other gender-related employment disparities by focusing attention on "common causes" of EEO variation. Failing to incorporate the concept of common causes into enforcement activities will risk future EEO progress (Deming, 1986). When applied to the EEO context, this suggests that special factors such as the actions of individual employers, have less influence on EEO outcomes than common factors that affect all employers in an industry. Whether or not the common cause predominance holds in the EEO context remains an open empirical question; however, there is no doubt that common causes of employment processes are substantial and consequential.

Bielby and Baron (1980) advocated "bringing the firms back in" to model and understand individual-level employment outcomes more completely. Sometimes overlooked, however, is that their paper also emphasized the importance of industry to firm-level outcomes. We overlay SPC with this sociological work to conceptualize industry as a common cause of employment outcomes at the firm level. At present, U.S. 
EEO enforcement agencies devote little attention to industry and to common causes of firm-level EEO performance. The results presented in Table II and Figure II provide vital guidance to policy makers who will also need to design a common cause remediation approach. Options include emphasizing one or a combination of the following: (a) industries with the worst overall EEO performance; (b1) the worst subcomponent of each industry (Finance - e.g., Equal Pay); (b2) the worst performer for each component (e.g., Hiring - transportation, communication and utilities industry); or (c) the combination of subcomponents with the greatest potential to eradicate gender employment disparities most quickly, which would require more complex mathematical analyses (Kolesar 1993a). Criteria "b1" and "b2" from above would ensure that common cause remediation efforts are spread over multiple industries but only under "b1" would every industry receive assistance and attention.

According to criterion "a", Scorecard results indicate that the mining and construction industry is the poorest EEO performer, with occupational segregation being its primary weakness (i.e., a standardized component value of -1.751), followed by glass ceiling and race/ethnic disparities. In order to more fully understand this occupational segregation, we encourage further investigation of this industry. For example, digging deeper we find that in the mining and construction industry, men are concentrated in production, craft and repair occupations (62\% of men versus $9 \%$ of women), while women are concentrated in administrative (34\% of women versus $13 \%$ of men) and technician positions (47\% of women versus $2 \%$ of men) (not presented in tables). Therefore, common cause remediation in the mining and construction industry should focus on industry-wide solutions to this extreme occupational segmentation. 
Worthy of future research is examination of potential correlates of EEO Scorecard results. We observe that two of the three more heavily unionized industries - mining and construction and transportation, communications and utilities - also had the worst EEO performance. One possibility is that contractually-based seniority systems in these industries slow EEO progress relative to less unionized industries. Or union pressure to reduce pay dispersion may have a secondary effect of decreasing the gender earnings gap, making EEO performance in these industries better than what it might otherwise have been (Elvira and Saporta, 2001). We also observe that two of the industries with better EEO performance - finance, insurance, and real estate; and service - contain occupations with high proportions of professionals. A relationship between proportions of white collar workers and positive EEO performance would be consistent with Leonard's (1985) finding that OFCCP compliance efforts were targeted to these types of occupations. On the other hand the opposite trends over time for these two industries (see Figure II) suggest a more complicated story.

\section{B. Contribution of the Systemic Gender EEO Scorecard}

The Systemic Gender EEO Scorecard is a comprehensive tool for assessing employer and industry EEO performance, aggregating outcomes on five EEO sub-components: equal pay, occupational segregation, glass ceiling issues, hiring outcomes, and race/ethnic EEO progress. Because the Scorecard assesses multiple employment processes, it is capable of accounting for complex forms of discrimination. The Scorecard makes it easier detect small or subtle gender biases, and biases that transform over time in response to regulatory pressure. For example, Figure II shows that the finance, insurance, and real estate industry appears to have made some real EEO progress over time; however, the Scorecard results for the Equal Pay component 
highlight a potentially serious unequal pay problem. Another benefit of assessing industry performance on five different potential forms of employment discrimination is that policy resources can be tailored to the type of gender disparities that are most prevalent in a particular industry. Finally, unlike current regulatory tools the Scorecard permits consideration of betweenand within-employer (or industry) sources of gender-related earnings differences (Petersen and Saporta, 2004) in a single metric. For all of these reasons, the Scorecard has the potential to move the overall economy towards greater gender parity as access and opportunities improve in each industry (Bergmann, 1974).

The Systemic Gender EEO Scorecard would be useful to both the EEOC and the OFCCP in enforcement and outreach efforts. For the EEOC, the Scorecard could serve as the metric for outlier identification and possible systemic charge development. For the OFCCP, the Scorecard could identify outlier federal contractors for compliance audits of their affirmative action plans and other human resource management practices, which could lead to sanctions and/or systemic charge development. Industry-level Scorecard results could provide valuable guidance to both agencies for expanded education and outreach and industry/agency partnerships. In fact, the similarity in potential benefits of the Scorecard for the two agencies raises the question of why the EEOC and OFCCP operate as separate entities. The greatest challenge regarding the Scorecard will be the political one of justifying more data collection from employers, especially given the fate of the OFCCP's EOS Survey (Federal Register 2006b). However, we believe that the reporting costs to employers will be offset by the fact that SPC methods provide inherent safeguards from arbitrary or random enforcement activity. Ultimately, policy makers will have to consider the needs of employees, workers, and the missions of the EEOC and OFCCP in 
improving current enforcement mechanisms and in promoting collaborative industry-based solutions.

The Systemic Gender EEO Scorecard was developed in the context of the increasing use of metrics in business and government to guide strategic decisions and target resources where they will be used most effectively. There are several other EEO-related scorecards that have been proposed. For example, Mehri, Giampetro-Meyer, and Runnels (2004) developed an EEO scorecard for inclusion into firms' annual Securities and Exchange Commission (SEC) reports. Internal EEO and corporate diversity metrics abound but they are usually not assessed relative to other firms or industries (e.g., Hubbard, 2004). There are also publications that evaluate the "best places to work" for women or minorities but these tend to include less objective or self-reported data on firm diversity performance than our scorecard (e.g., Minority Law Journal, 2006). In short, our Scorecard appears to be the most developed in terms of measurement and theory, and it appears to be of most direct use in EEO enforcement agencies.

\section{Public Policy Recommendations}

We recommend substantial technical changes to the process of systemic charge development by the EEOC and OFCCP by incorporating statistical methods of outlier identification for investigation and possible sanctions (Shewhart, 1939; Deming, 1986). This will involve the use of control charts that treat most employer EEO performance as normal variation within the industrial system, but will highlight some employer EEO performance as special, or non-random variation. Enforcement agencies should consider systemic charges only for employers with substantially worse EEO performance than their industry peers (Bendick and Egan, 2000; Leonard, 1985). Recognizing outlier employers as special causes has the dual benefit of avoiding unproductive systemic investigations as well as detecting egregious employer 
discrimination that goes unreported to the EEOC at present (Petersen and Saporta, 2004; Selmi, 2006).

There are serious concerns with relying on employee complaints as the primary means of eradicating employment discrimination (Hirsh 2008; Selmi, 2006; Krieger \& Fiske, 2006). However, we recommend retention of the complaint-filing system for a couple of reasons. Complaints that result in substantial EEO settlements likely have an impact within the industry. For example, it is possible that EEOC sex discrimination settlements with Morgan Stanley (U.S. EEOC 2004) and other financial firms contributed to the significant improvement in overall EEO performance in that industry. Second, meritorious discrimination complaints can serve as evidence of special causes of EEO performance variation. That is, complaints are analogous to situations where a manager unambiguously observes the misconduct or intentional poor performance of an individual worker. Treating meritorious complaints in this manner would alleviate the possibility that SPC could fail to identify some actual systemic discriminators. Retention of the complaint system is also important to maintaining employees' procedural fairness perceptions regarding discrimination claiming.

Our second policy recommendation is that the EEOC and OFCCP incorporate industry considerations more explicitly into their enforcement and outreach activities. All EEOC Districts should explicitly identify particular industries for enforcement and other interventions, perhaps modeled on OSHA's Local Emphasis Programs (OSHA, 2008a). In addition, both the EEOC and OFCCP should promote substantive partnerships with industry trade groups and employers to develop innovative approaches to remove industry-related impediments to EEO progress. These partnerships should acknowledge that individual non-outlier employers within an industry have less than complete control over their EEO outcomes, due to the constraints posed by industry- 
related norms, structures, business environments, and other factors (Hawawini et al., 2003; McGahan and Porter, 2002). Relatedly, according to SPC, it would be counterproductive to increase the numbers of investigations of employers in industries with poor EEO records, unless these employers are in fact outliers.

Collaborative enforcement agency / business efforts can be modeled on the quality improvement methods used by corporations. For example, one manufacturing plant utilizes teams comprised of production workers, a production engineer, and a facilitator to share information on current and longer-term production issues; and to help remediate special and common causes of variation (Field and Sinha, 2005). Collaboration could also be modeled on the well-developed cooperative programs of the Occupational Safety and Health Administration (OSHA, 2008b). For example, under the Alliance Program, OSHA works with trade groups and other stakeholders to develop compliance assistance tools and to share information with employers. The primary advantages of these collaborative approaches is that they tap into the knowledge of those who are most familiar with the processes in question (Field and Sinha, 2005), and that collaboration is more likely to be embraced by employers than are sanctions (Gilliland and Hoffman, 2004).

The key to the success of our proposal is a substantial increase in the resources allocated to the EEOC and the OFCCP, for purposes of developing innovative solutions to industry barriers to EEO progress. Merely shifting funds from enforcement activities will result ineffective application of SPC concepts, for several reasons. First, even in the presence of outlier evidence, systemic discrimination charge preparation requires substantial amounts of investigator and statistician resources (Silverman, 2006). Second, substantial resources will need to be devoted to the establishment of agency-employer collaborative relationships, joint idea 
generation, and implementation of the innovative solutions. It can not be underscored more forcefully that these collaborative efforts must be substantive rather than symbolic or incremental (Edelman, 1992; Kolesar, 1993b). Finally, cooperative programs will take place with no expected reduction in the numbers of employee discrimination complaints, at least in the shortterm. Ultimately, policy makers will have to determine the best mix of current enforcement mechanisms and collaborative industry-based efforts to promote equal employment opportunity.

\section{Limitations and Future Research}

New proposals such as the application of SPC to EEO enforcement require greater conceptual leaps than incremental contributions, and there are some areas in the paper that we would like to acknowledge in this vein. First, consistent with SPC, we make the assumption that some and perhaps most gender disparities in the U.S. result from common causes rather than special causes (Shewhart, 1939; Deming, 1986). However, the possibility exists that industry employment process variation is due primarily to special causes (e.g., employer strategies, strong gender and race / ethnic differences in preferences or life experiences). Fortunately, although this concern has implications for policy-related resource allocations, it does not change our study's recommendations regarding the adoption of complementary systemic enforcement and education approaches, based in SPC logic, by the EEOC and OFCCP.

A second major limitation of the paper is that we have considered industry in less complexity than its operation in actual employment processes. To be most effective, enforcement agencies and employers need to refine, or disaggregate broad industry categories in order to generate the most useful policy ideas for reducing gender disparities. Moreover, methods for examining firms operating in multiple industries will need to be developed, and regional and relevant labor market factors will have to be added in to the equation. All efforts should consider 
the possibility that the importance of industry to firm-level outcomes will differ by sector (McGahan and Porter, 2002). As a starting point, we recommend an economy-wide replication of Leonard's (1985) study using EEOC and OFCCP data to provide a very useful snapshot of current EEO enforcement processes in the U.S.

\section{Conclusion}

The premise of our paper is that in order to effectively reduce gender-related employment disparities in the U.S. economy the employment processes of entire industries must change. We suggest the application of statistical process control as a technical and conceptual tool for understanding employer variation in EEO outcomes, and for guiding policy interventions. We recommend the Systemic Gender EEO Scorecard or a similar comprehensive metric because it more readily captures complex forms of discrimination than current measures.

An SPC approach at the industry level using the Systemic Gender Scorecard has the potential to benefit a diverse group of stakeholders: agency personnel with limited enforcement resources, employers seeking to improve EEO practices or gain employment-related efficiencies, and of course, women seeking non-discriminatory workplaces. Tomaskovic-Devey and colleagues (2006) are somewhat pessimistic regarding future equal employment opportunity progress absent more powerful public policy interventions. It is our hope that the new lens of statistical process control will provide a strong rationale for innovation in EEO enforcement. 


\section{References}

Akerlof, George A. 1985. "Discriminatory, Status-Based Wages Among Tradition-Oriented, Stochastically Trading Coconut Producers.” Journal of Political Economy 93: 265-276.

Anderson, John C., Manus Rungtusanatham, and Roger G. Schroeder. 1994. “A Theory of Quality Management Underlying the Deming Management Method.” Academy of Management Review 18: 472-509.

Ashenfelter, Orley and Timothy Hannan. 1986. "Sex Discrimination and Product Market Competition: The Case of the Banking Industry." Quarterly Journal of Economics 101(1): 149-74.

Ashforth, Blake E. and Fred A. Mael. 1989. "Social Identity Theory and The Organization." Academy of Management Review 14: 20-39.

Bayart, Denis. 2006. “The Fact-Theory Dialogue in an Industrial Context: The Case of Statistical Quality Control.” European Management Review 3: 87-99.

Becker, Brian E., Mark A. Huselid, and Dave Ulrich. 2001. The HR Scorecard. Cambridge: Harvard Business School.

Becker, Gary. 1993. Human Capital: A Theoretical and Empirical Analysis, with Special Reference to Education ( $3^{\text {rd }}$ Edition). Chicago: University of Chicago Press.

Bendick, Marc. 2007. Statement of Marc Bendick, Jr., Ph.D. U.S. EEOC Meeting of February 28, 2007, Washington, D.C. to Launch E-Race Initiative. http://eeoc.gov/abouteeoc/meetings/2-28-07/bendick.html. Accessed July 14, 2008.

Bendick, Marc and Mary Lou Egan. 2000. “Changing Workplace Cultures to Reduce Employment Discrimination. Presentation to the Conference on Low Wage Workers in the New Economy, May 25, 2000, Washington, DC.

Bergmann, Barbara R. 1974. "Occupational Segregation, Wages and Profits when Employers Discriminate by Race and Sex.” Eastern Economic Journal 1: 103-110.

Baron, James N. and William T. Bielby. 1980. "Bringing the Firms Back In: Stratification, Segmentation, and the Organization of Work." American Sociological Review 45: 737765.

Black, Sandra E., and Elizabeth Brainerd. 2002. "Importing Equality? The Impact of Globalization on Gender Discrimination." Industrial and Labor Relations Review 57: $540-559$. 
Blau, Francine D., Marianne A. Ferber, and Anne E. Winkler. 2006. The Economics of Women, Men, and Work (5 ${ }^{\text {th }}$ edition). Upper Saddle River, NJ: Prentice-Hall.

Browne, Irene and Joya Misra. 2003. "The Intersection of Gender and Race in the Labor Market." Annual Review of Sociology 29: 487-513.

Cartwright, Bliss and Patrick Ronald Edwards. 2003. "Some Implications of Segregation Research for Civil Rights Enforcement in Employment.” Working Paper. Washington, DC: U.S. EEOC.

Coleman, Major G. 2004. "Racial Discrimination in the Workplace: Does Market Structure Make a Difference?" Industrial Relations 43: 660-689.

Corbett, Charles J., Maria J. Montes-Sancho and David A. Kirsch. 2005. "The Financial Impact of ISO 9000 Certification in the United States: An Empirical Analysis.” Management Science 51: 1046-1059.

Dacin, M. Tina. 1997. "Isomorphism in Context: The Power and Prescription of Institutional Norms." Academy of Management Journal 40: 46-81.

Duncan, Otis D. and Beverly Duncan. 1955. "A Methodological Analysis of Segregation Indexes." American Sociological Review 20: 210-17.

Edelman, Lauren B. 1992. "Legal Ambiguity and Symbolic Structures: Organizational Mediation of Civil Rights Law." The American Journal of Sociology 97: 1531-1576.

Edwards, Patrick Ronald. 1991/1992. “Choices that Increase Compliance.” Policy Studies Review 10: 6-27.

Elvira, Marta and Ishak Saporta. 2001. "How Does Collective Bargaining Affect the Gender Pay Gap. Work and Occupations 28: 469-490.

Federal Register. 2006a. "Obligation to Solicit Race and Gender Data for Agency Enforcement Purposes.” March 29, 2004, 41 CFR Part 60-1 RIN 1215-AB45, 69: 16446-16450.

Federal Register. 2006b. "Affirmative Action and Nondiscrimination Obligations of Contractors and Subcontractors; Equal Opportunity Survey." September 8, 2006, 41 CFR Part 60-2 RIN 1215-AB53, 71: 53032-53042.

Field, Joy M. and Kingshuk K. Sinha. 2005. “Applying Process Knowledge for Yield Variation Reduction: A Longitudinal Field Study.” Decision Sciences 36: 159-186.

Gersen, Jacob E. 2007. “Markets and Discrimination.” New York University Law Review 82: 689737. 
Gilliland, David I. and K. Douglas Hoffman. 2004. "Examining a Key Aspect of Agency-toBusiness Relationships: The Effects of Regulatory Control on the Satisfaction of Regulated Firms.” Journal of Business-to-Business Marketing 11: 75-102.

Goldman, Barry M. 2003. “The Application of Referent Cognitions Theory to Legal-Claiming by Terminated Workers: The Role of Organizational Justice and Anger.” Journal of Management 29: 705-728.

Grabov, P. 1998. “SPC's Effectiveness Prediction and Analysis.” ASQ's Annual Quality Congress Proceedings 52: 688-696.

Graham, Mary E. Graham, Julie L. Hotchkiss, and Barry Gerhart. 2000. "Discrimination by Parts: A Fixed Effects Analysis of Starting Pay Differences Across Gender." Eastern Economic Journal 26: 9-27.

Granovetter, Mark. 1985. "Economic Action and Social Structure: The Problem of Embeddedness." The American Journal of Sociology 91: 481-510.

Greene, William H. 1981. "Sample Selection Bias as a Specification Error: Comment." Econometrica 49: 795-8.

Hawawini, Gabriel, Venkat Subramanian, and Paul Verdin. 2003. "Is Performance Driven by Industry- or Firm-Specific Factors? A New Look at the Evidence." Strategic Management Journal 24(1): 1-16.

Heckman, James. 1979. "Sample Selection Bias as a Specification Error." Econometrica 47: 15361.

Heckman, James J. and Kenneth I. Wolpin. 1976. "Does the Contract Compliance Program Work? An Analysis of Chicago Data.” Industrial and Labor Relations Review 29: 544564.

Hirsh, C. Elizabeth. 2008. "Settling for Less? Organizational Determinants of DiscriminationCharge Outcomes." Law \& Society Review 42: 239-274.

Hodgson, Morgan D. and Ronald S. Cooper. 2000. “OFCCP Contractor Survey; New Worker Economic Opportunity Law; EEOC Compliance Manual Revisions and Charge Statistics for 1999." Employment Relations Today 27: 81-88.

Hotchkiss, Julie L. and M. Melinda Pitts. Forthcoming. "The Demand Side of the Penalty for Intermittent Labor Market Behavior." Applied Economics Letters.

Hubbard, Edward E. 2004. The Diversity Scorecard. Burlington, MA: Elsevier. 
Johnson, George and Gary Solon. 1986. "Estimates of the Direct Effects of Comparable Worth Policy.” American Economic Review 76: 1117-1125.

Johnson, William R. 1978. "Racial Wage Discrimination and Industrial Structure.” Bell Journal of Economics 9: 70-81.

Kolesar, Peter J. 1993a. "The Relevance of Research on Statistical Process Control to the Total Quality Movement.” Journal of Engineering and Technology Management 10: 317-338.

Kolesar, Peter J. 1993b. "Vision, Values, Milestones: Paul O’Neill Starts Total Quality at Alcoa.” California Management Review 35: 133-165.

Krieger, Linda Hamilton. 1995. "The Content of Our Categories: A Cognitive Bias Approach to Discrimination and Equal Employment Opportunity." Stanford Law Review 47: 11611248.

Krieger, Linda Hamilton and Susan T. Fiske. 2006. "Behavioral Realism in Employment Discrimination Law: Implicit Bias and Disparate Treatment." California Law Review 94: 997-1062.

Krueger, Alan B. and Lawrence H. Summers. 1988. "Efficiency Wages and the Inter-Industry Wage Structure.” Econometrica. 56: 259-293.

Latzko, William J. and David M. Saunders. 1995. Four Days with Dr. Deming. Reading, MA: Addison Wesley.

Leonard, Jonathan S. 1985. "Affirmative Action as Earnings Redistribution: The Targeting of Compliance Reviews.” Journal of Labor Economics, 3: 363-384.

Leonard, Jonathan S. 1990. "The Impact of Affirmative Action Regulation and Equal Employment Law on Black Employment." The Journal of Economic Perspectives 4: 4763.

MacCarthy, B.L. and Thananya Wasusri. 2002. "A Review of Non-Standard Applications of Statistical Process Control (SPC) Charts.” International Journal of Quality and Reliability Management 19: 295-320.

McAdams, R.H. 1995. "Cooperation and Conflict: The Economics of Group Status Production and Race Discrimination." Harvard Law Review 108: 1003-1084.

McGahan, Anita M. and Michael E. Porter, 2002. "What Do We Know About Variance in Accounting Profitability?" Management Science 48: 834-851. 
Mehri, Cyrus, Andrea Giampetro-Meyer, and Michael B. Runnels. 2004. "One nation indivisible: The use of diversity report cards to promote transparency, accountability, and workplace fairness." Fordham Journal of Financial and Corporate Law 9: 395-448.

Miller, Danny and Ming-Jer Chen. 1996. "Nonconformity in Competitive Repertoires: A Sociological View of Markets." Social Forces 74: 1209-1234.

MinorityLawJournal.com. 2006. Diversity scorecard - 2006. http://www.law.com/jsp/mlj/diversityScorecard.jsp. Accessed August 31, 2006.

Nelson, Lloyd S. 2003. "When Should the Limits on a Shewhart Control Chart Be Other Than a Center Line +/-3-Sigma?" Journal of Quality Technology 424-425.

Petersen, Trond, and Ishak Saporta. 2004. "The Opportunity Structure for Discrimination.” The American Journal of Sociology 109: 852-901.

Rath and Strong / Aon Management Consulting. 2003. Six Sigma Leadership Handbook. Hoboken, NJ: John Wiley \& Sons.

Reskin, Barbara F. 2000. “The Proximate Causes of Employment Discrimination.” Contemporary Sociology 29: 319-329.

Rose, Stephen J. and Heidi I. Hartmann. 2004. "Still a Man's Labor Market: The Long-Term Earnings Gap.” Washington, DC: Institute for Women's Policy Research.

Selmi, Michael 2006. "Was the Disparate Impact Theory a Mistake?" UCLA Law Review 71: 701-782.

Shewhart, Walter A. 1939. Statistical Method from the Viewpoint of Quality Control. New York: Dover.

Short, Jeremy C., David J. Ketchen, Timothy B. Palmer, and G. Tomas M. Hult. 2007. "Firm, Strategic Group, and Industry Influences on Performance.” Strategic Management Journal, 28: 147-167.

Silberman, Mickey. “Applicant Tracking and Systemic Discrimination: What You Don't Know Can Hurt You." Webcast by Jackson / Lewis law firm for the Society for Human Resource Management. February 27, 2008, www.shrm.org

Silverman, Leslie. 2006. Systemic Task Force Report to the Chair of the Equal Employment Opportunity Commission. Washington, DC: U.S. EEOC. 
Stangor, Charles, Janet K. Swim, Katherine Van Allen, and Gretchen Sechrist. 2002. "Reporting Discrimination in Public and Private Contexts." Journal of Personality and Social Psychology 82: 69-74.

U.S. Department of Commerce. 2008. The Paperwork Reduction Act and Informations Collections Policy. http: //ocio.os.doc.gov/ITPolicyandPrograms/Information _Collection/dev01_003742. Accessed August 29, 2008.

U.S. Department of Labor. 2007. Median Weekly Earnings by Detailed Occupation and Sex, 2007 Annual Averages. http://www.bls.gov/cps/cpsaat39.pdf. Accessed August 29, 2008.

U.S. Department of Labor. 2008a. Improvements at OFCCP Produce Record Financial Recoveries for Record Number of American Workers in FY07. http://www.dol.gov/esa/ofccp/enforc07.pdf. Accessed March 28, 2008.

U.S. Department of Labor. 2008b. Facts on Executive Order 11246. Washington, DC: Office of Federal Contract Compliance Programs (OFCCP). http://dol.gov/esa/regs/compliance/ofccp/aa.htm. Accessed March 28, 2008.

U.S. Department of Labor. 2008c. Federal Contractor Selection System (FCSS) - Questions and Answers. http://www.dol.gov/esa/regs/compliance/ofccp/faqs/fcssfaqs.html. Accessed March 28, 2008.

U.S. Department of Labor. 2008d. OFCCP's Enforcement Procedures. http://www.gov/esa/ofccp/aboutof.html. Accessed July 15, 2008.

U.S. Equal Employment Opportunity Comission (EEOC). 2007a. Performance and Accountability Report FY 2007. http://www.eeoc.gov/abouteeoc/plan/par/2007/strategic plan.html\#objective. Accessed July 15, 2008.

U.S. EEOC. 2007b. Equal Employment Opportunity Commission Consolidated Statements of Net Cost For the Years Ended September 30, 2007 and 2006. http://www.eeoc.gov/abouteeoc/plan/par/2007/financial_statements.html. Accessed July $\underline{15}, 2008$.

U.S. EEOC. 2006. Strategic Plan for Fiscal Years 2007-2012. http://www.eeoc.gov/abouteeoc/plan/strategic_07-12/index.html. Accessed March 28, 2008. 
U.S. EEOC. 2004. EEOC and Morgan Stanley Announce Settlement of Sex Discrimination Lawsuit. http://www.eeoc.gov/press/7-12-04.html. Accessed August 28, 2008.

U.S. General Accounting Office. 1995. Equal Employment Opportunity. DOL Contract Compliance Reviews Could Better Target Federal Contractors. September 1995, GAO/HEHS-95-177.

U.S. Occupational Safety and Health Administration (OSHA). 2008a. Local Emphasis Programs. http://www.osha.gov/dep/local emphasis_programs.html. Accessed July 29, 2008.

U.S. OSHA. 2008b. Cooperative Programs. http://www.osha.gov/dcsp/compliance_assistance/index_programs.html. Accessed July 29, 2008.

Weichselbaumer, Doris, and Rudolf Winter-Ebmer. 2006. "Rhetoric in economic research: The case of gender wage differentials." Industrial Relations 45: 416-436.

White, Harrison C. 1981. “Where Do Markets Come From?” The American Journal of Sociology 87: 517-547.

Wooten, Lynn Perry and Erika Hayes James. 2004. "When Firms Fail to Learn. The Perpetuation of Discrimination in the Workplace." Journal of Management Inquiry 13: 23-33. 


\section{Appendix A}

Detail on Scorecard Components

1) Equal Pay Component. This will be indicated by the existence of a negative and significant gender coefficient in a regression of hourly earnings on employees' gender, race, job characteristics, and human capital characteristics. The wage regression will also control for selfselection into the labor market (Heckman, 1979; Greene, 1981). This essentially amounts to a two-step procedure. In the first step, an estimate of each worker's probability of being observed in the labor market is calculated. This probability is included as a regressor in the second step estimation of the wage equation.

The coefficient on the female dummy variable is what represents the selectivity-corrected percentage wage differential. ${ }^{15}$ This component of the Scorecard is designed to capture equal pay discrimination within employers and is designed to encourage employers to use consistent pay-setting practices and monitor any gender-related pay differences that can not be justified by merit, seniority, or any factor other than sex. At present, the Equal Employment Opportunity Commission (EEOC) receives relatively few equal pay complaints, in part because few employees have access to the pay information of their co-workers. For the years 1992 through 2000, Equal Pay Act charges constituted less than 2\% of individual charge filings with the EEOC (U.S. EEOC, 2006).

2) Occupational Segregation Component. This will be measured by the well-known Duncan dissimilarity Scorecard (Duncan and Duncan 1955). The Duncan Scorecard falls between zero and one and indicates the percent of either men or women that would have to change occupations in order for the distributions across occupations to be equal. The closer the Scorecard is to zero, the more equal are the distributions of men and women across occupations. It is calculated as: 
Occupational Segregation ${ }_{\mathrm{j}}=\frac{1}{2} \sum_{i=1}^{n}\left|M_{i j}-F_{i j}\right|$,

where $n$ is the number of occupations represented in industry $j, M_{i j}$ is the proportion of men employed by industry $j$ found in occupation $i$, and $F_{i j}$ is the proportion of women employed by industry $j$ found in occupation $i$. Because women usually work in lower-paying occupations, this component is designed to capture excessive and potentially discriminatory occupational segregation, within employers. Thus employers are encouraged to examine their job placement processes, as well as consider the implementation of programs to train and encourage women to enter non-traditional fields (e.g., computer programming). It is possible to score poorly on Occupational Segregation by reverse occupational segmentation (e.g., if men are overrepresented in a traditionally-female occupation); however, these situations would be relatively rare, and likely would have to be analyzed by the EEOC on a case by case basis.

3) Glass Ceiling Component. This will be measured as 1 minus the proportion of managerial and professional positions that are held by women in the industry. Attention to this component is designed to encourage employers to eradicate hiring and promotion discrimination, as well as institute programs to encourage and assist women in reaching the upper levels of organizations.

4) Hiring Component. This measure is simply the proportion of occupations represented in each firm in which women are under-represented relative to the relevant labor market. Or this component could be modified to consider the degree of under-representation in hiring for each occupation. For example, if only 25 percent of occupation A is made up of women in an industry, whereas market-wide, 60 percent of that occupation is made up of women, then women are considered under-represented in that occupation in that industry. If women are underrepresented in 25 percent of all occupations in an industry, then the industry's Hiring Component would be equal to 0.25 . Attention to this component will encourage employers to devote 
attention to their recruitment and selection practices to ensure that they do not result in hiring discrimination.

5) Related discrimination component. This component is comprised of the outcome measures on the first four components across racial/ethnic lines. This component is designed to recognize the potential interconnectedness of race, gender, and other types of discrimination, and the potential for employers who are discriminatory in one area (e.g., gender) to be discriminatory in other areas. Supporting this approach, there is a large literature on the inter-relatedness of gender and race, and how being a woman and a member of a racial or ethnic minority group could result in greater levels of discrimination (see for example, Browne and Misra, 2003).

A key issue in constructing the Scorecard is the way in which the five components are combined into a single number. We recommend calculation of the simple arithmetic mean. The arithmetic mean Scorecard for industry $j$ is given by:

$$
I_{A j}=\frac{1}{5} \sum_{i=1}^{5} C_{i j},
$$

where $C_{i}$ is the $i$ th component for industry $j$. The advantage of the arithmetic mean is that it is a well-known statistic representing a linear average of each of the components. Since all components of the Scorecard are measured on a scale between 0 and 1, the arithmetic mean seems a reasonable choice. A disadvantage is that each component is equally weighted and that extremely poor performance in one are can be exactly offset by extremely good performance in another area. Of course different weights can be applied to the different components as might be deemed necessary by past poor performance in one area or by a particular policy emphasis of the evaluator. 
Table I. Sample Means (std. dev.) for the Year 2000, By Industry.

\begin{tabular}{|c|c|c|c|c|c|c|c|}
\hline & $\begin{array}{c}\text { Full } \\
\text { Sample }\end{array}$ & $\begin{array}{c}\text { Finance, } \\
\text { Insurance, } \\
\text { Real Estate }\end{array}$ & $\begin{array}{l}\text { Mining, } \\
\text { Construc- } \\
\text { tion }\end{array}$ & $\begin{array}{l}\text { Manufac- } \\
\text { turing }\end{array}$ & Service & $\begin{array}{l}\text { Transportation, } \\
\text { Commmuni- } \\
\text { cation, Utilities }\end{array}$ & $\begin{array}{c}\text { Retail \& } \\
\text { Whole- } \\
\text { sale } \\
\text { Trade } \\
\end{array}$ \\
\hline $\begin{array}{l}\text { Proportion of all } \\
\text { workers }\end{array}$ & 1.00 & 0.08 & 0.08 & 0.20 & 0.35 & 0.08 & 0.22 \\
\hline Proportion female & 0.48 & 0.64 & 0.10 & 0.35 & 0.64 & 0.28 & 0.50 \\
\hline Wage/hr & $\begin{array}{l}\$ 15.78 \\
(10.39)\end{array}$ & $\begin{array}{l}\$ 18.43 \\
(12.38)\end{array}$ & $\begin{array}{l}\$ 16.65 \\
(9.69)\end{array}$ & $\begin{array}{l}\$ 16.79 \\
(9.67)\end{array}$ & $\begin{array}{l}\$ 15.72 \\
(10.80)\end{array}$ & $\begin{array}{l}\$ 17.93 \\
(11.38)\end{array}$ & $\begin{array}{l}\$ 12.75 \\
(8.55)\end{array}$ \\
\hline Hours/wk & $\begin{array}{l}40.24 \\
(9.62)\end{array}$ & $\begin{array}{l}40.81 \\
(8.29)\end{array}$ & $\begin{array}{l}42.06 \\
(8.71)\end{array}$ & $\begin{array}{l}42.11 \\
(6.67)\end{array}$ & $\begin{array}{c}38.60 \\
(10.81)\end{array}$ & $\begin{array}{l}42.10 \\
(9.90)\end{array}$ & $\begin{array}{c}39.50 \\
(10.13)\end{array}$ \\
\hline Nonwhite (1=yes) & 0.15 & 0.14 & 0.09 & 0.14 & 0.18 & 0.17 & 0.14 \\
\hline College (1=yes) & 0.19 & 0.31 & 0.08 & 0.16 & 0.23 & 0.17 & 0.14 \\
\hline Union (1=yes) & 0.09 & 0.01 & 0.17 & 0.15 & 0.06 & 0.26 & 0.05 \\
\hline \multicolumn{8}{|l|}{ Occupation: } \\
\hline Professional & 0.28 & 0.36 & 0.14 & 0.24 & 0.43 & 0.21 & 0.12 \\
\hline Technical & 0.31 & 0.59 & 0.07 & 0.17 & 0.25 & 0.28 & 0.51 \\
\hline Service & 0.12 & 0.03 & 0.003 & 0.01 & 0.23 & 0.03 & 0.17 \\
\hline Craft & 0.13 & 0.02 & 0.56 & 0.19 & 0.05 & 0.16 & 0.07 \\
\hline Labor & 0.16 & 0.004 & 0.23 & 0.39 & 0.04 & 0.32 & 0.12 \\
\hline No. of Obs. & 33,662 & 2,692 & 2,540 & 6,862 & 11,671 & 2,640 & 7,257 \\
\hline
\end{tabular}

Note: Professional occupation encompasses professional, administrative, and managerial occupations. Technical occupation encompasses technical and related support. Service occupation encompasses service only. Craft occupation encompasses precision production, craft, and repair occupations. Labor occupation includes handlers, equipment cleaners, helpers, and laborers. 
Table II. Industry EEO Scorecard and Standardized Scorecards for the Year 2000.

\begin{tabular}{|c|c|c|c|c|c|c|c|}
\hline $\begin{array}{l}\text { Scorecard } \\
\text { Component }\end{array}$ & $\begin{array}{c}\text { Finance, } \\
\text { Insurance, } \\
\text { Real Estate }\end{array}$ & $\begin{array}{l}\text { Mining, } \\
\text { Construc- } \\
\text { tion } \\
\end{array}$ & $\begin{array}{c}\text { Manufac- } \\
\text { turing }\end{array}$ & Service & $\begin{array}{l}\text { Transportation, } \\
\text { Commmuni- } \\
\text { cation, Utilities }\end{array}$ & $\begin{array}{c}\text { Retail \& } \\
\text { Whole- } \\
\text { sale } \\
\text { Trade }\end{array}$ & $\begin{array}{l}\text { Market } \\
\text { Average } \\
\text { (std dev) } \\
\end{array}$ \\
\hline Equal Pay & $\begin{array}{l}0.2487 \\
\mathbf{- 1 . 2 9 8}\end{array}$ & $\begin{array}{l}0.1998 \\
\mathbf{0 . 8 8 7 6}\end{array}$ & $\begin{array}{l}0.2340 \\
\mathbf{- 0 . 6 4 1}\end{array}$ & $\begin{array}{l}0.1938 \\
\mathbf{1 . 1 5 7 2}\end{array}$ & $\begin{array}{l}0.2347 \\
\mathbf{- 0 . 6 7 3}\end{array}$ & $\begin{array}{c}0.2070 \\
\mathbf{0 . 5 6 8}\end{array}$ & $\begin{array}{c}0.2197 \\
(0.0224)\end{array}$ \\
\hline $\begin{array}{l}\text { Occupational } \\
\text { Segregation }\end{array}$ & $\begin{array}{c}0.1743 \\
\mathbf{0 . 7 5 2}\end{array}$ & $\begin{array}{l}0.6966 \\
\mathbf{- 1 . 7 5 1}\end{array}$ & $\begin{array}{c}0.1657 \\
\mathbf{0 . 7 9 3}\end{array}$ & $\begin{array}{l}0.2619 \\
\mathbf{0 . 3 3 2 3}\end{array}$ & $\begin{array}{l}0.4609 \\
\mathbf{- 0 . 6 2 1}\end{array}$ & $\begin{array}{l}0.2280 \\
\mathbf{0 . 4 9 4 7}\end{array}$ & $\begin{array}{c}0.3312 \\
(0.2087)\end{array}$ \\
\hline Glass Ceiling & $\begin{array}{c}0.4252 \\
\mathbf{1 . 0 9 5}\end{array}$ & $\begin{array}{l}0.7545 \\
\mathbf{- 1 . 1 2 3}\end{array}$ & $\begin{array}{l}0.6876 \\
\mathbf{- 0 . 6 7 2}\end{array}$ & $\begin{array}{l}0.4118 \\
\mathbf{1 . 1 8 5 2}\end{array}$ & $\begin{array}{l}0.7027 \\
\mathbf{- 0 . 7 7 4}\end{array}$ & $\begin{array}{l}0.5448 \\
\mathbf{0 . 2 8 9 4}\end{array}$ & $\begin{array}{c}0.5878 \\
(0.1485)\end{array}$ \\
\hline Hiring & $\begin{array}{c}0.4000 \\
\mathbf{0 . 7 0 7}\end{array}$ & $\begin{array}{c}0.6000 \\
\mathbf{0}\end{array}$ & $\begin{array}{c}0.6000 \\
\mathbf{0}\end{array}$ & $\begin{array}{l}0.2000 \\
\mathbf{1 . 4 1 4 2}\end{array}$ & $\begin{array}{l}1.0000 \\
\mathbf{- 1 . 4 1 4}\end{array}$ & $\begin{array}{l}0.8000 \\
\mathbf{- 0 . 7 0 7}\end{array}$ & $\begin{array}{c}0.6000 \\
(0.2828)\end{array}$ \\
\hline $\begin{array}{l}\text { Related } \\
\text { Discrimination }\end{array}$ & $\begin{array}{c}0.2440 \\
\mathbf{1 . 2 3 0}\end{array}$ & $\begin{array}{c}0.4864 \\
\mathbf{- 1 . 0 5}\end{array}$ & $\begin{array}{l}0.4450 \\
\mathbf{- 0 . 6 5 7}\end{array}$ & $\begin{array}{l}0.2633 \\
\mathbf{1 . 0 6 2 7}\end{array}$ & $\begin{array}{l}0.3492 \\
\mathbf{0 . 2 4 9 5}\end{array}$ & $\begin{array}{l}0.4654 \\
\mathbf{- 0 . 8 5 1}\end{array}$ & $\begin{array}{c}0.3755 \\
(0.1056)\end{array}$ \\
\hline $\begin{array}{l}\text { Overall } \\
\text { Industry } \\
\text { Scorecard }\end{array}$ & $\begin{array}{c}0.2984 \\
\mathbf{1 . 0 4 7}\end{array}$ & $\begin{array}{l}0.5275 \\
\mathbf{- 1 . 1 0 9}\end{array}$ & $\begin{array}{l}0.4065 \\
\mathbf{- 0 . 0 3 2}\end{array}$ & $\begin{array}{l}0.2595 \\
\mathbf{1 . 2 7 5 3}\end{array}$ & $\begin{array}{l}0.5162 \\
\mathbf{- 1 . 0 0 8}\end{array}$ & $\begin{array}{l}0.4224 \\
\mathbf{- 0 . 1 7 4}\end{array}$ & $\begin{array}{c}0.4028 \\
(0.1124)\end{array}$ \\
\hline
\end{tabular}

Note: The values in bold type correspond to the standardized value of the component. The standardized score is calculated as the market average for that component minus the industry's score on that component, divided by the market standard deviation for that component. 
Figure IA. Range Chart for EEO Scorecard, by Employer

(Over 5-Year Period)

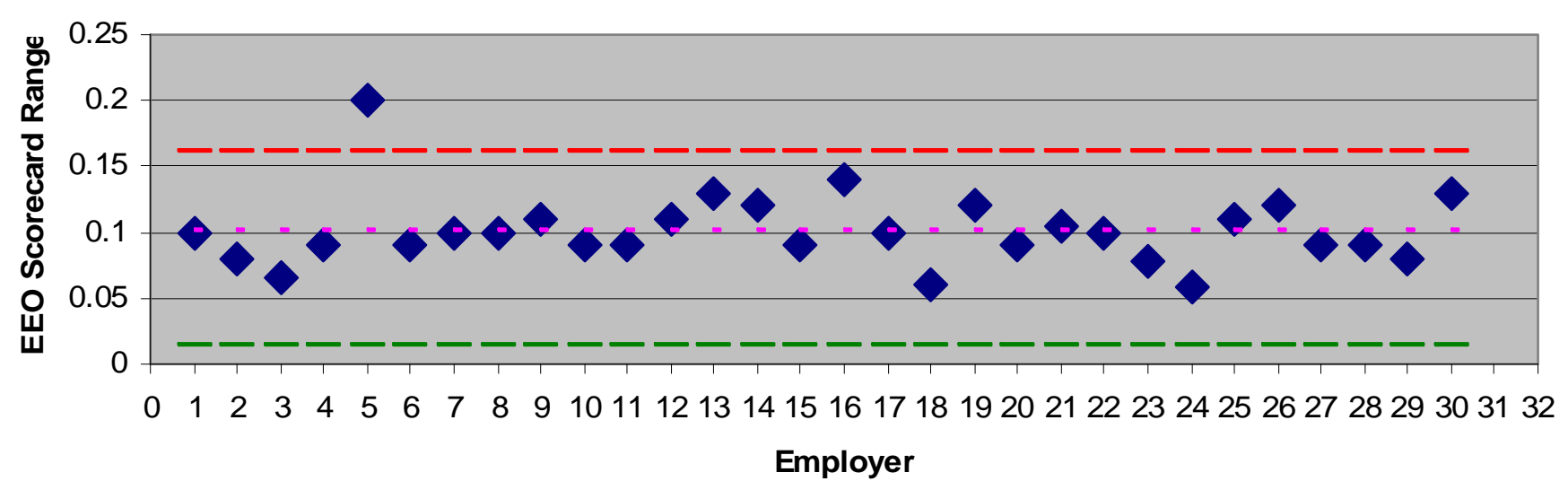

- Range of EEO Scores Over 5 Yrs. - Average Range - UCL (poor) - LCL (good)

Figure IB. X-Bar Chart for EEO Scorecard in Year 2000, by Employer

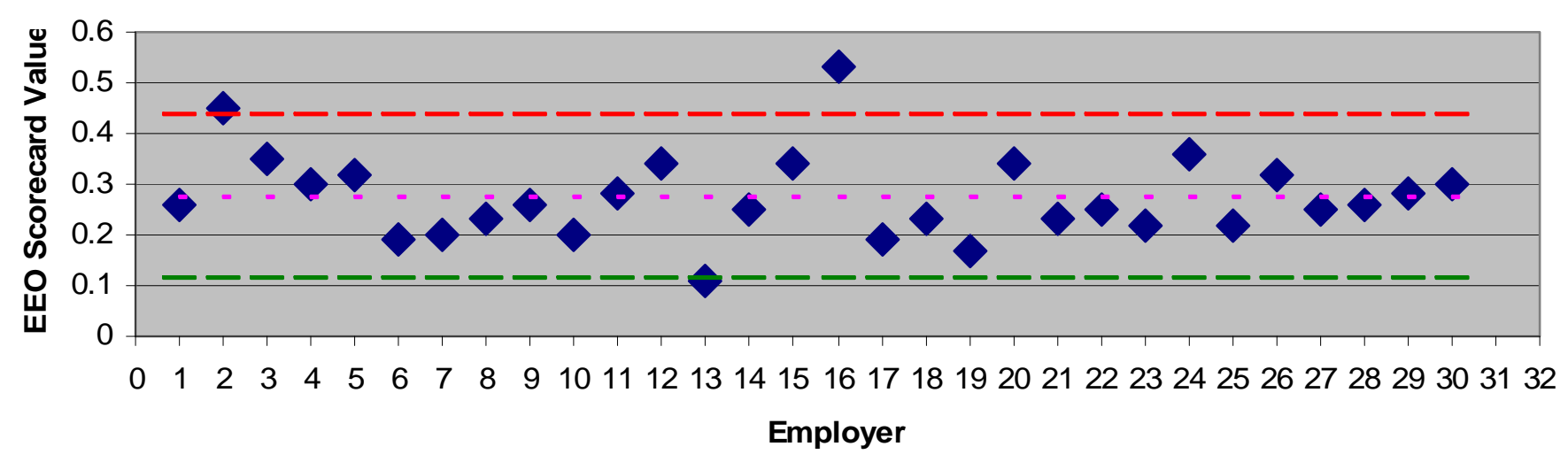

- Avg. EEO Scorecard, Year 2000 - Overall Avg. - UCL (poor) - LCL (good) 
Figure II. Industry EEO Performance Over Time

Standardized Index

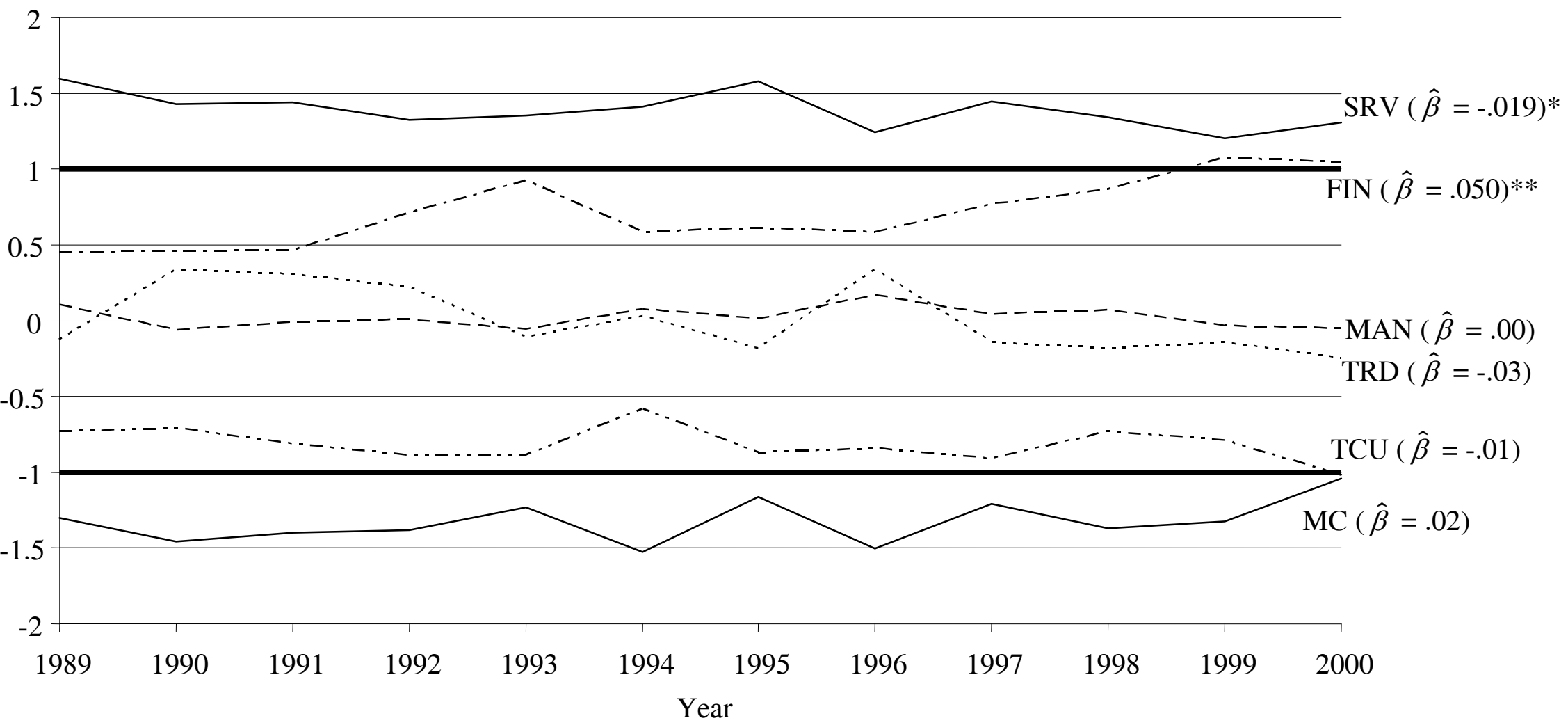

Significance: $\quad * \mathrm{p}>.05 \quad * * \mathrm{p}>.01$

Notes

FIN - Finance, Insurance, Real Estate

MAN - Manufacturing

MC - Mining, Construction

SRV - Service

TCU - Transportation, Communication, Utilities TRD - Retail \& Wholesale Trade

Estimated trend coefficients $(\hat{\beta})$ are reported along with their significance levels. 
${ }^{1}$ We choose to focus on industry, rather than other potential common causes of employer actions such as business strategy (Short, Ketchen, Palmer and Hult, 2007), because of the difficulties in accessing competitive information on individual employers.

${ }^{2}$ SPC practitioners attempt to balance and minimize Type I errors (i.e., finding a specific cause of variation when there is none) and Type II errors (i.e., not detecting a specific cause of variation when one exists) when developing and using control charts (Shewhart, 1939; Deming, 1986). Initial total quality management efforts, reflecting the systems focus of the engineering profession, minimized the potential for Type I errors (Bayart, 2006). Six Sigma programs continue this tradition but more heavily emphasize the reduction of Type II errors (Kolesar, 1993a).

${ }^{3}$ Non-construction contractors with 50 or more employees and $\$ 50,000$ or more in business with the federal government, are required "to develop and implement a written affirmative action program (AAP) for each establishment" (U.S. DOL, 2008e). Construction contractors and subcontractors with $\$ 10,000$ or more in federal business are also subject to affirmative action requirements, but their plans and goals are developed by the OFCCP.

4 In Fiscal Year 2007 the EEOC spent \$14,983,933 on training and outreach excluding revenue generated; with a total of $\$ 286,937,746$ spent on private sector efforts (U.S. EEOC, 2007b).

${ }^{5}$ The variable of occupation will influence employment processes and EEO outcomes as well (Blau et al., 2006). However, we focus on industry in this paper because of the natural contrast it provides to the employer-focused enforcement policies of the EEOC and the OFCCP, combined with the fact that employing firms are nested within industries. This decision also looks ahead to our later discussion of policy-making implications.

${ }^{6}$ The other major OFCCP enforcement tool is de-barment of federal contractors, an option which is rarely employed (Leonard, 1990). For example from 2000-2007, it appears that less than 10 contractors were de-barred (epls.gov, March 28, 2008).

${ }^{7}$ Related components can be added for other protected groups, such as the disabled.

${ }^{8}$ Examination of firm-level EEO outcomes will rely primarily on outlier identification rather than pattern identification. For a summary of patterns of instability by Western Electric, Boeing, and others, see: http://www.qualitytrainingportal.com/resources/spc/spc_adv_patterns_instability.htm. 
${ }^{9}$ The threshold for intervention or assistance will depend upon policy makers balancing of Type I and Type II errors as well as the economic costs of pursuing and correcting special causes (Nelson, 2003).

${ }^{10}$ The statistical process control literature also recommends studying positive outliers for evidence of best practices that could be shared with others. Just as the identification of negative outliers should be systematic and based upon the principles of SPC, so too should the identification of positive outliers. Neither the EEOC nor the OFCCP employ SPC-level process to recognize stellar employers; however, we do not discuss this issue further as our focus is on employers with poor EEO performance.

${ }^{11}$ The observations that comprise the range calculations are not independent in that employers' EEO performance in earlier years will affect later EEO performance.

${ }^{12}$ Due to the small size of the agriculture industry and the unique features of the public sector, the Agriculture and Public Administration industries are excluded from the present analysis.

13 The sample sizes for each year are as follows: 1989 - 37,093; 1990 - 40,924; 1991 - 40,808; 1992 - 40,346; 1993 - 39,828; 1994 - 36,235; 1995 - 31,840; 1996 - 32,042; 1997 - 32,781; 1998 32,$936 ; 1999-32,751 ; 2000-33,662$.

${ }^{14}$ The standardized score is calculated as the market average for that component minus the industry's score on that component, divided by the market standard deviation for that component. 15 The Equal Pay Component is measured by occupations within industries, which is the closest approximation possible with CPS data. If employer-level data were available, the preferred measure would consist of jobs within firms. 